\title{
Implementasi Corporate Social Responsibility Berlandaskan Filosofi Tri Hita Karana Pada Lembaga Perkreditan Desa
}

\author{
Desak Komang Indah Purwati ${ }^{1}$ \\ Agus Indra Tenaya ${ }^{2}$ \\ ${ }^{1}$ Fakultas Ekonomi dan Bisnis Universitas Udayana (Unud), Bali, Indonesia \\ email: desakindah015@gmail.com / telp: +6282236919564 \\ ${ }^{2}$ Fakultas Ekonomi dan Bisnis Universitas Udayana (Unud), Bali, Indonesia
}

\begin{abstract}
ABSTRAK
Penelitian ini dilakukan di LPD Desa Adat Kuta. Tujuan penelitian ini adalah untuk mengetahui implementasi Corporate Social Responsibility berlandaskan nilai - nilai filosofi Tri Hita Karana pada Lembaga Perkreditan Desa (LPD). Penelitian ini menggunakan pendekatan kualitatif dengan metode studi kasus. Oleh karena itu peneliti sendiri yang menjadi informan penelitian. Informan adalah pelaku CSR di LPD Desa Adat Kuta dan informan lainnya yang terkait. Pengumpulan data dilakukan dengan wawancara, observasi non partisipan, dan dokumentasi. Hasil penelitian ini menunjukan bahwa implementasi CSR pada LPD Desa Adat Kuta telah dilakukan secara terpadu. CSR Terpadu menghasilkan tiga sinergi implementasi, yaitu implementasi masyarakat (Pawongan), lingkungan (Palemahan), dan hal-hal yang berkaitan dengan Tuhan (Parhyangan).

Kata kunci: Corporate Social Responsibility, Tri Hita Karana, LPD, CSR Terpadu.
\end{abstract}

\section{ABSTRACT}

This research was conducted in LPD Desa Adat Kuta. This research purpose is to know the implementation of Corporate Social Responsibility based on Tri Hita Karana philosophy values at Lembaga Perkreditan Desa (LPD). This research uses qualitative approach with case study method. Therefore researchers themselves become research informant. The informants are the CSR perpetrators in LPD Desa Adat Kuta and other relevant informants. The data was collected by interview, non participant observation, and documentation. The results show that integrated of CSR. It produces three forms of implementation which are synergic, namely of the implementation in the community (Pawongan), in the environment (Palemahan), and the matters relating to God (Parhyangan).

Keywords: Corporate Social Responsibility, Tri Hita Karana, LPD, Integrated CSR.

\section{PENDAHULUAN}

Lembaga Perkreditan Desa (LPD) merupakan lembaga keuangan yang menghimpun dan menyalurkan dana masyarakat yang beroperasi pada suatu wilayah administrasi desa adat dengan berdasarkan atas kekeluargaan (Sujana dan Sutika, 2013). LPD terus mengembangkan lembaganya dengan cara mempererat ikatan kekeluargaan dengan masyarakat sekitar LPD (Bagiada, 2015). Menurut 
Bank Indonesia (2016), pada triwulan III aset LPD berjumlah Rp15,5 triliun ini menandakan Lembaga Perkreditan Desa (LPD) merupakan lembaga keuangan nonbank yang memiliki asset terbesar. Sebagai lembaga keuangan nonbank yang memiliki asset terbesar di Bali, LPD memiliki tanggung jawab sosial dan ekonomi pada masyarakat di desa. Peraturan Daerah Provinsi Bali Nomor 3 Tahun 2017 mengenai perubahan ketiga atas Peraturan Daerah Provinsi Bali Nomor 4 Tahun 2012 tentang Lembaga Perkreditan Desa (LPD) menyatakan bahwa keuntungan bersih yang diterima LPD yaitu 5\% untuk dana sosial dan $20 \%$ digunakan untuk dana pembangunan desa. Berdasarkan peraturan diatas, menandakan bahwa suatu LPD memiliki peranan dalam mensejahterakan masayarakat Desa.

Corporate Social Responsibility (CSR) merupakan suatu konsep mengenai upaya yang dilakukan oleh lembaga atau perusahaan sebagai bentuk tanggung jawab terhadap stakeholders, dan lingkungan sekitar di mana lembaga atau perusahaan itu berada. Segala kegiatan operasional yang di lakukan oleh perusahaan/lembaga sering kali menghasilkan dampak eskternal yang harus ditanggung oleh stakeholders dan lingkungannya. Dari pengertian diatas, wajar bila perusahaan/lembaga memperhatikan kepentingan dan nilai tambah bagi stakeholders maupun lingkungan sekitarnya. Namun dalam praktiknya masih saja terdapat kendala yang dikarenakan kurang tegasnya pemerintah mengenai CSR dan status untuk CSR ini masih merupakan voluntare disclosure atau baru dilakukan secara sukarela (Bagiada dan Darmayasa, 2015). Corporate Social Responsibility (CSR) menurut Elkington merupakan kewajiban perusahaan 
terhadap konsumen, karyawan, pemegang saham, masyarakat, dan ekologis dalam semua aspeknya. Kewajiban yang dimaksud tersebut jauh lebih luas, tidak hanya menyangkut kewajiban untuk mematuhi perundang-undangan yang ada, tetapi juga kewajiban dalam arti moral. Pernyataan tersebut sejalan dengan teori legitimasi yang menyatakan pengaruh masyarakat luas dapat menentukan alokasi sumber keuangan dan sumber ekonomi lainnya, perusahaan/lembaga cenderung menggunakan kinerja berbasis lingkungan dan pengungkapan informasi lingkungan untuk membenarkan atau melegitimasi aktivitas perusahaan/lembaga di mata masyarakat (Gray et al., 1995). Jadi pengungkapan CSR sangat penting bagi sebuah perusahaan/lembaga untuk membangun, mempertahankan, dan melegitimasi kontribusi perusahaan/lemabaga dari sisi ekonomi, sosial, dan politik (Damayanti, 2011). Selain teori legitimasi, terdapat 2 teori lain yang mendukung pengungkapan CSR yaitu teori stakeholders (Degaan 2004:929) dan teori pemberian (Kusuma, 2017). Teori stakeholders menjelaskan perusahaan dalam melakukan usaha perlu memperhatikan seluruh item yang berkaitan dengan kondisi perusahaan dan memberikan manfaat bagi para stakeholders (Ratih, 2016). Teori pemberian (gift theory) banyak diungkapkan oleh Marcel Mauss (1992;2002) yang menyatakan, "tidak ada pemberian yang bersifat cumacuma. Seluruh pemberian akan diikuti oleh bentuk pemberian kembali yang dikenal juga dengan imbalan.” Konteks CSR identik dengan implementasi dari teori pemberian dan stakeholders. CSR sebagai pemberian sangat baik untuk tujuan membina dan meningkatkan hubungan. 
Desak Komang Indah Purwati dan Agus Indra Tenaya. Implementasi...

Corporate Social Responsibility yang dilaksanakan oleh perusahaan/lembaga kental kaitannya dengan budaya masyarakat di lingkungan perusahaan/lembaga, serta spiritual (berhubungan dengan Tuhan Yang Maha Esa). Hal ini sejalan dengan hasil penelitian oleh Asocio (2004) di mana karakter Corporate Social Responsibility, khususnya di kawasan Asia Pasifik (termasuk Indonesia) lebih dipengaruhi oleh tradisi panjang menghargai keluarga, jaringan sosial, agama, dan budaya yang bervariasi, yang membuat karakter Corporate Social Responsibility di kawasan Asia Pasifik berbeda dengan kawasan Eropa atau Amerika Utara. Adanya kaitan antara budaya dan pelaksanaan CSR juga ditunjukkan dari hasil penilitian Wang dan Juslin pada tahun 2009. Penelitian yang dilakukan Wang dan Juslin (2009) ini memperoleh hasil mengenai Harmony Approach to CSR (HCSR) yang merupakan definisi baru bagi CSR. Adanya anggapan mengenai konsep CSR barat yang digunakan tidak sejalan dengan realitas pasar dan budaya Cina ini memunculkan HCSR. HCSR sangat melekat pada budaya Tionghoa dan karakteristik Cina, yaitu konfusianisme. Konfusianisme yaitu berkaitan dengan hubungan harmonis antar pribadi dan taonisme yang berkaitan dengan hubungan harmonis antara manusia dan alam, sehingga pendekatan ini memiliki arti "menghormati alam dan mencintai masyarakat". Dengan adanya hubungan antara pelaksanaan CSR dan kearifan budaya tradisional, hal ini akan membantu perusahaan/lembaga untuk menjalankan CSR dengan inisiatifnya sendiri dan memberikan cara baru bagi perusahaan/lembaga dalam usaha untuk meningkatkan kinerja CSR-nya ini menurut hasil penelitian Wang dan Juslin. Hasil penelitian Wang dan Juslin ini 
juga memberikan peranan bagi studi CSR di masa yang akan datang, khususnya untuk menerangkan CSR dalam beragam latar budaya dan mengharapkan penerpan CSR diselaraskan dengan budaya dan kondisi nasional suatu negara.

Kultur masyarakat Indonesia adalah masyarakat religius yang memiliki kepercayaaan dan keyakinan bahwa Tuhan Yang Maha Esa sebagai pencipta dan penguasa tertinggi alam semesta ini (Pertiwi, 2013). Begitu juga dengan masyarakat di Bali, masyarakat di Bali yang dominan beragama Hindu memiliki nilai luhur Budaya yaitu Tri Hita Karana. Budaya Tri Hita Karana (THK) merupakan konsep kehidupan yang mengedepankan prinsip-prinsip keselarahan, kebersamaan, dan keseimbangan antara tujuan ekonomi, pelestarian lingkungan dan budaya, estetika dan spiritual (Tenaya, 2007). Berhubungan dengan budaya masyarakat, biasanya perusahaan atau lembaga dalam melaksanakan kegiatan CSR selalu selaras dengan budaya atau tradisi masyarakat setempat, dengan harapan masyarakat ataupun lingkungan sekitar perusahaan dapat ikut serta memberikan apresiasinya dan merasakan manfaat dari pelaksanaan CSR tersebut. Konsep Corporate Social Responsibility (CSR) menekankan pada dua unsur, yaitu keharmonisan hubungan antara perusahaan dengan masyarakat serta keharmonisan hubungan perusahaan dengan lingkungan. Sementara itu, budaya Tri Hita Karana berisi tentang keharmonisan hubungan antara manusia dengan Tuhan (parhyangan), hubungan antara sesama manusia (pawongan) dan hubungan antara manusia dengan alam semesta (palemahan). Unsur masyarakat dalam pelaksanaan CSR memiliki keterkaitan dengan unsur pawongan dalam konsep Tri Hita Karana. Unsur alam dan lingkungan memiliki kaitan dengan 
unsur palemahan dalam budaya Tri Hita Karana. Akan tetapi, dalam budaya Tri Hita Karana, unsur alam dan lingkungan (palemahan) maupun unsur masyarakat (pawongan) akan selalu berhubungan dengan Tuhan Yang Maha Esa sebagai pencipta alam semesta (parhyangan). Jadi, dapat dikatakan bahwa konsep Corporate Social Responsibility yang dikenal saat ini memiliki keharmonisan hubungan dengan konsep Tri Hita Karana yang dimiliki oleh masyarakat Bali.

LPD sebagai lembaga keuangan yang bertujuan untuk membangun perekonomian masayarakat desa, haruslah melaksanakan aktivitas bisnis yang berlandaskan pada nilai-nilai budaya yang membuat aktivitas ini dapat berguna bukan hanya pada orang-orang yang terlibat pada perusahaan/lembaga tersebut, tetapi juga dengan lingkungan sekitar dan seluruh alam semesta. Jadi implementasi Corporate Social Responsibility (CSR) dalam operasional LPD di Bali sebaiknya berpegang pada Filosofi Tri Hita Karana karena THK merupakan filosofi hidup umat hindu.

Penelitian mengenai implementasi Corporate Social Responsibility (CSR) pada LPD sebelumnya sudah pernah dilakukan oleh Damayanti (2011) dan Bagiada (2015). Penelitian Damayanti (2011) hanya mendeskripsikan Corporate Social Responsibility (CSR) pada LPD dan menggunakan pendekatan naratif. Sedangkan Bagiada (2015) menggunakan metode studi kasus interpretif dengan lokasi penelitian LPD Desa Adat Legian. Pada penelitian ini ingin memperbaiki keterbatasan pada penelitian sebelumnya. Penelitian ini lebih menekankan pada aspek implementasi CSR yang berlandaskan filosofi THK dan menggunakan metode studi kasus. Penelitian ini juga menggunakan lokasi yang berbeda dengan 
penelitian sebelumnya yaitu Lembaga Perkreditan Desa (LPD) Desa Adat Kuta. Dipilihnya Desa Adat Kuta sebagai lokasi penelitian dengan pertimbangan Desa ini salah satu Desa wisata di Bali yang banyak dikunjungi wisatawan mancanegara dengan budaya berbeda, namun Desa Adat Kuta masih mampu menerapkan filosofi Tri Hita Karana pada organisasi tradisional setempat.

Berdasarkan uraian latar belakang, maka dapat dirumuskan pokok permasalahan dalam penelitian ini yaitu: "bagaimanakah implementasi Corporate Social Responsibility berlandaskan nilai-nilai filosofi Tri Hita Karana pada Lembaga Perkreditan Desa (LPD) Desa Adat Kuta?” dan tujuan yang hendak dicapai dalam penelitian ini adalah untuk mengetahui implementasi Corporate Social Responsibility berlandaskan nilai - nilai filosofi Tri Hita Karana pada Lembaga Perkreditan Desa (LPD) Desa Adat Kuta.

Manfaat teoritis dari penelitian ini diharapkan mampu berkontribusi pada teori legitimasi, teori stakeholders dan gift theory dalam aspek lokal genius Manfaat praktisnya yaitu penelitian ini diharapkan dapat menjadi referensi LPD dalam menyusun pedoman penerapan CSR berlandaskan filosofi Tri Hita

\section{Karana.}

\section{METODE PENELITIAN}

Penelitian ini menggunakan desain penelitian kualitatif diskriptif. Metode penelitian kualitatif adalah penelitian yang menggunakan latar alamiah, dengan maksud menafsirkan fenomena yang terjadi dan dilakukan dengan jalan melibatkan berbagai metode yang ada (Denzin dan Lincoln 1987). Moleong (2016) memaparkan bahwa dalam penelitian kualitatif peneliti sendiri atau 
dengan bantuan orang lain merupakan alat pengumpul data utama. Informan yang dijadikan sebagai sumber data dalam penelitian ini dapat dilihat pada tabel 1

Tabel 1.

Daftar Informan

\begin{tabular}{llll}
\hline No & Nama & Keterangan & \\
\hline 1 & Bapak Gede Buda Artha & Kepala LPD Desa Adat Kuta & \\
2 & Bapak Swarsa & Bendesa Adat Desa Adat Kuta & \\
3 & Ibu Putu Suryani & Pegawai LPD Desa Adat Kuta & \\
4 & Ibu Dwi & Pegawai LPD Desa Adat Kuta & \\
5 & Ibu Yeni & Masyarakat lokal sekaligus menjadi & \\
& & & \\
Sumber: Data Diolah, 2018 & &
\end{tabular}

Penelitian ini dilakukan pada LPD di Desa Adat Kuta. LPD Desa Adat Kuta dipilih sebagai lokasi penelitian karena prestasi yang dimiliki, yaitu LPD Desa Adat Kuta merupakan LPD dengan aset dan laba tertinggi di kabupaten Badung, LPD Desa Adat Kuta memperoleh penghargaan dari Bali International Customers Award pada tahun 2011 dan 2013. Metode yang digunakan penelitian ini adalah metode studi kasus. Yin (2011: 23) menjelaskan bahwa terdapat tiga karakteristik utama metode penelitian studi kasus yang membedakannya dengan strategi ataupun metode penelitian lainnya.

Analisis studi kasus dalam penelitian ini bertujuan untuk memberikan pandangan, pengetahuan tentang suatu fenomena penerapan nilai filosofi Tri Hita Karana pada program CSR di LPD Desa Adat Kuta.

Teknik analisis data pada penelitian ini terdiri dari 5 langkah, yaitu : (a) Pengumpulan data, data penelitian diperoleh menggunakan teknik wawancara. Wawancara dilakukan kepada 5 orang informan yang mengetahui serta memahami pengimplementasian CSR berlandaskan Tri Hita Karana. Data lain diperoleh dari laporan keuangan tahunan LPD Desa Adat Kuta, (b) pengelompokan data dalam proses ini peneliti melakukan pengelompokkan data 
yang telah diperoleh dari hasil wawancara dan dari laporan keungan tahunan LPD Desa Adat Kuta, (c) reduksi data, dalam proses ini peneliti melakukan pemilihan, pemusatan perhatian pada penyederhanaan, dan transformasi data kasar yang telah dikelompokkan, (d) penyajian data, setelah melakukan reduksi data, data hasil wawancara disajikan dalam bentuk uraian tentang program Corporate Social Responsibility (CSR) dengan penerapan nilai filosofis Tri Hita Karana, (e) nterpretasi data dan penarikan kesimpulan, setelah melakukan penyajian data, kemudian melakukan pemaknaan terhadap data yang ada sesuai dengan objek penelitian dan kemudian menganalisis data yang ada dengan menggabungkan data yang didapat dari informan dan data sekunder. Selanjutnya peneliti memberikan kesimpulan atas hasil yang didapat dan memberikan saran - saran.

\section{HASIL DAN PEMBAHASAN}

Desa Adat Kuta adalah satu lembaga otonom adat Bali berdasarkan hukum adat Bali untuk mencapai tujuan bersama berlandaskan ajaran filosofi Tri Hita Karana. Desa Adat Kuta sebagai kota dengan cita rasa dunia, terdiri atas 13 Banjar dan jumlah penduduk sampai tanggal 30 Juni 2016 adalah 2.205 KK. Desa Adat Kuta mewarisi sejumlah tanah pelaba (aset) pura yang bisa dikelola untuk mendanai kegiatan-kegiatan ritual maupun pembangunan fisik dan nonfisik di desa adat. Tanah-tanah pelaba pura milik Desa Adat Kuta tersebar di beberapa tempat dan kini dikelola sebagai usaha produktif, di antaranya Pasar Seni Kuta I di Jalan Dewi Sartika, Pasar Seni Kuta II di Jalam Poppies II, kompleks kios seni di Jalan Singosari, Pasar Senggol Desa Adat Kuta di Jalan Blambangan serta Unit Pengelola Pantai Desa Adat Kuta. 
LPD Desa Adat Kuta juga merupakan salah satu pelaba dalam bentuk usaha yang bergerak di bidang lembaga keuangan. LPD Desa Adat Kuta lahir dari sebuah semangat dan rasa jengah (tertantang) untuk membangun krama dan Desa Adat Kuta yang lebih kokoh, baik dari sisi ekonomi, sosial maupun budaya. Pendirian LPD Desa Adat Kuta berawal dari mendapat "hadiah" berupa izin pendirian LPD karena Desa Adat Kuta sudah mengikuti lomba desa adat. Pada tanggal 25 November 1995, LPD Desa Adat Kuta mulai beroperasi. Pendirian LPD Desa Adat Kuta ini berdasarkan Peraturan Daerah (Perda) Provinsi Bali Nomor 2 tahun 1988 dan Keputusan Gubernur Kepala Daerah Tingkat I Bali Nomor 619 tahun 1995. Perda Provinsi Bali Nomor 2 tahun 1988 telah disempurnakan menjadi Perda Provinsi Bali Nomor 8 Tahun 2002, dan yang terakhir adalah Perda Provinsi Bali Nomor 3 tahun 2017 tentang Perubahan Ketiga atas Peraturan Daerah Provinsi Bali Nomor 4 Tahun 2012.

Modal awal LPD Desa Adat Kuta tercatat sebesar Rp 31.600.000. Modal ini berasal dari Desa Adat Kuta sebesar Rp 25.000.000, bantuan Pemerintah Tingkat I Bali sebesar Rp 5.000.000 serta bantuan Pemerintah Tingkat II Badung sebesar Rp 1.600.000. Pada awal didirikan, kantor LPD Desa Adat Kuta masih sangat sederhana yang terletak di lantai II Pasar Seni Desa Adat Kuta. LPD Desa Adat Kuta baru diresmikan pada 12 Januari 1996 bertepatan dengan peresmian kantor. Peresmian dilakukan Gubernur Bali, Ida Bagus Oka. LPD Desa Adat Kuta diresmikan setelah lebih dari sebulan beroperasi. Peralatan penunjang kegiatan LPD pada tahun pertama masih sangat minim. Tenaga yang dimiliki juga masih terbatas, hanya didukung oleh tiga orang pengurus dan tiga orang pegawai. Tiga 
pengurus LPD Desa Adat Kuta pada saat itu yakni I Wayan Gede Buda Artha SE (Ketua), Ni Wayan Netriani (Tata Usaha) serta Ni Wayan Suwarsih (Kasir) dan tiga orang pegawai LPD pada saat itu yakni I Gede Astawa, Ni Made Parminiwati serta Ni Wayan Mustika Ari.

Di tahun kedua puluh dua ini LPD Desa Adat Kuta sudah semakin berkembang pesat. Jumlah pegawai yang dimiliki sudah mencapai 69 orang dengan fasilitas pendukung yang semakin lengkap, mulai dari sarana komputer yang memadai, fasilitas pendukung kegiatan yang cukup hingga fasilitas gedung yang representatif. Laba dan aset yang dicapai LPD Kuta hingga tahun 2018 yaitu sebesar Rp 80.000.000.000 dan aset sudah mencapai Rp 480.000.000.000.

Visi LPD Desa Adat Kuta yaitu : Membangun LPD Desa Adat Kuta, Memberdayakan Desa Adat Kuta”. Visi ini diambil dari cita-cita yang mendasari kelahiran LPD di Bali yakni memperkokoh bangunan ekonomi masyarakat serta menopang pembangunan dan kegiatan adat, budaya dan sosial di desa adat.

Visi ini diterjemahkan LPD Desa Adat Kuta dengan moto “ Mitra Utama Membangun Desa". Moto ini mengandung makna agar tumbuh kesadaran di kalangan krama Desa Adat Kuta bahwa dukungan yang diberikan kepada LPD melalui pemanfaatan layanan LPD sesungguhnya merupakan sebuah upaya membangun Desa Adat Kuta. Artinya, menabung, menempatkan deposito atau pun meminjam di LPD Desa Adat Kuta sama artinya dengan ber-yadnya untuk desa Adat. Dasar pemikirannya, LPD merupakan salah satu pelaba (aset) desa adat. Seperti halnya pelaba desa lainnya, LPD dikelola untuk memberikan 
manfaat bagi krama dan desa adat, baik manfaat ekonomi maupun manfaat sosialbudaya.

Keuntungan yang didapat LPD Desa Adat Kuta dikembalikan ke krama melalui desa adat. Ini tercermin dalam pembagian keuntungan kepada desa adat yang disebut sebagai sarana pembangunan. Dana pembangunan inilah yang kemudian digunakan untuk mendukung kegiatan pembangunan di desa adat, baik dalam bentuk pembangunan fisik dan nonfisik yang meliputi aspek-aspek $T r i$ Hita Karana yakni Parhayangan (menjaga keharmonisan hubungan antara manusia dengan Ida Sang Hyang Widhi Wasa/Tuhan Yang Maha Esa) Pawongan (memelihara keserasian hubungan antara manusia dengan manusia), serta Palemahan (merawat keselarasan hubungan antara manusia dengan lingkungannya).Visi "Membangun LPD Desa Adat Kuta, Memberdayakan Desa Adat Kuta" diturunkan ke dalam misi yang lebih terfokus. LPD Desa Adat Kuta menetapkan 6 misi.

Misi pertama, meningkatkan keamanan dalam mengurus dan mengelola LPD melalui pemahaman ajaran agama dan etika berusaha sehingga terwujud pengurus, pengelola dan pengawas yang professional berdasarkan pengabdian, komitmen serta idealism untuk tetap lestarinya Desa Adat Kuta. LPD Desa Adat Kuta patut dikelola secara professional berlandaskan kepada prinsip-prinsip pengelolaan lembaga keuangan yang baik, benar, dan sehat. Profesionalisme itu diperkokoh dengan komitmen dan kesadaran untuk ngayah (mengabdi) membangun krama dan desa adat. 
Kedua, mendorong pembangunan ekonomi kerakyatan yang mengacu pada keunggulan komparatif dan kompetitif dalam rangka lebih memberdayakan sektor ekonomi masyarakat pedesaan. LPD Desa Adat Kuta diharapkan menjadi penggerak ekonomi berbasis kerakyatan. Kehadiran LPD Adat Kuta harus menjadi bandul untuk menjaga keseimbangan kegiatan ekonomi kepariwisataan Kuta yang selama ini cenderung dinikmati para pemodal besar kepada ekonomi yang bertumpu pada kesejahteraan masyarakat Kuta.

Ketiga, membuat sistem kerja dalam rangka mempercepat pelayanan secara lebih mudah, murah, mengarah dan terjangkau dengan tidak mengabaikan aturan dan sistem kerja LPD. Harus disadari, LPD menghadapi persaingan yang ketat dengan lembaga-lembaga keuangan lainnya. Karena itu, harus terus diupayakan sistem kerja yang semakin baik dengan harapan terciptanya pelayanan kepada masyarakat yang lebih mudah, murah, mengarah dan terjangkau. Artinya, LPD Desa Adat Kuta patut memberikan akses yang lebih besar bagi masyarakat Kuta.

Keempat, mendorong berkembangnya prakarsa masyarakat dalam melestarikan aset desa adat dalam rangka pembangunan pariwista yang berlandaskan pada adat dan budaya. LPD mesti menjadi motivator bagi krama desa dalam membangun desa adta serta perkembangan pariwisata di Kuta yang berbasis adat dan budaya.

Kelima, berpartisipasi dalam mengembangkan berbagai potensi seperti usaha perdagangan, pasar desa, industri kecil, kerajinan rumah tangga, pertanian, perternakan dan jasa. LPD Desa Adat Kuta disiapkan untuk menjadi pendorong 
tumbuh kembangnya aneka usaha kecil, mikro dan menengah di kalangan masyarakat Kuta sehingga mampu menopang industry kepariwisataan Kuta yang berkembang sangat pesat.

Keenam, pendayagunaan usaha-usaha peningkatan taraf hidup krama desa dan membantu krama Desa Adat Kuta menjaga ketahanan ekonomi guna ikut bersaing dalam pasar bebas yang bersifat global. LPD Desa Adat Kuta diharapkan menjadi benteng perekonomian masyarakat kuta dalam menghadapi tantangan global seiring dengan perkembangan kepariwisataan Kuta.

Berdasarkan visi dan misi diatas ini menandakan Lembaga Perkreditan Desa (LPD) Desa Adat Kuta adalah lembaga keuangan milik desa yang terlahir dengan tujuan untuk membangun desa adat sekaligus memberdayakan desa. LPD merupakan lembaga keuangan milik desa pakraman yang telah berkembang dan memberikan manfaat sosial, ekonomi, dan budaya kepada anggotanya. Dengan demikian, LPD harus dibina dan ditingkatkan kinerjanya agar semakin baik dan terus berkembang guna meningkatkan taraf kehidupan di desa. LPD juga merupakan wadah kekayaan desa adat yang dimiliki oleh warga adat.

Peraturan Daerah Nomor 3 tahun 2017 tentang LPD diatur mengenai pembagian keuntungan LPD menjadi enam bagian, $60 \%$ untuk cadangan modal, $20 \%$ untuk pembangunan dan pemberdayaan desa, $10 \%$ untuk jasa produksi, $5 \%$ untuk pemberdayaan masyarakat dan 5\% untuk dana sosial. Pemberian $20 \%$ keuntungan LPD untuk dana pembangunan desa merupakan bukti kongkret fungsi LPD sebagai pelaba desa. LPD Desa Adat Kuta didirikan memang dengan tujuan untuk menopang kebutuhan dana di desa adat, baik untuk pembangunan 
fisik maupun nonfisik. Selain dana pembangunan desa adat, LPD juga memiliki kewajiban menyisihkan 5\% dari keuntungan untuk dana sosial. Dana sosial merupakan kewajiban yang harus dilakukan LPD sebagai sebuah lembaga usaha. Keberadaan dana sosial merupakan bentuk tanggung jawab sosial (social responsibility) kepada masyarakat yang telah mendukung usaha LPD selama ini. Perkembangan dana pembangunan desa dan dana sosial bisa dilihat pada Gambar 1. Sejak didirikan tahun 1996 hingga akhir tahun 2017, jumlah dana pembangunan yang diserahkan LPD Desa Adat Kuta Kepada Desa Adat Kuta sudah mencapai Rp 22.579.542.742. Sementara jumlah total dana sosial yang telah disalurkan mencapai Rp 5.744.566.529.

Berikut ini adalah pernyataan Bendesa Desa Adat Kuta (Bapak Swarta) :

"Keuntungan dari LPD yaitu ditentukan 20\% dari laba bersih setiap tahunnya memang diperuntukan untuk kas Desa Adat Kuta, jadi kas Desa Adat Kuta ini dipergunakan untuk membiayai pembangunan desa berlandaskan filosofi Tri Hita Karana"

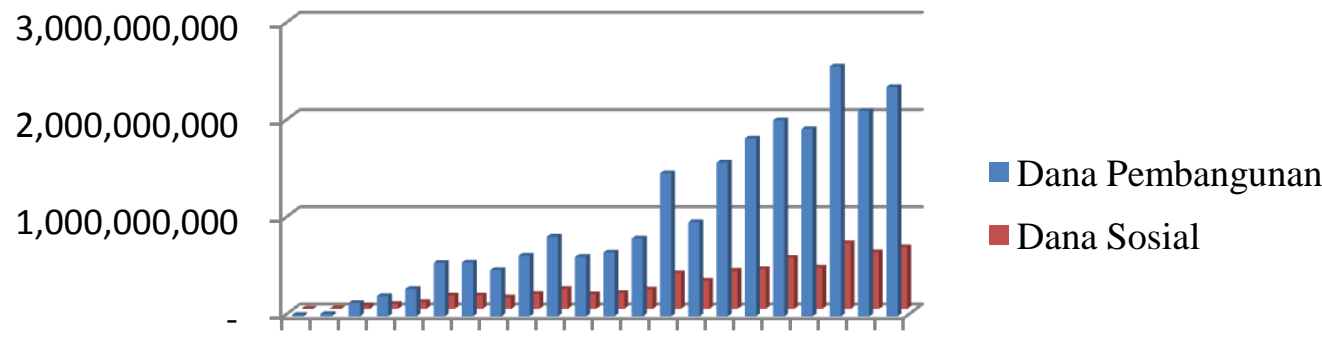

$\begin{array}{lllllllllll}1 & 3 & 5 & 7 & 9 & 11 & 13 & 15 & 17 & 19 & 21\end{array}$

Sumber : LPD Desa Adat Kuta Data diolah, 2018

Gambar 1.

Perkembangan Dana Pembangunan Desa dan Dana Sosial LPD Desa Adat Kuta 
Dilihat dari grafik dan pernyataan Bendesa Adat Kuta maka dapat disimpulkan bahwa LPD dalam masyarakat Desa khususnya Desa Adat Kuta mempunyai tanggung jawab sosial kepada masyarakat di sekitar tempat LPD berdiri.

Implementasi Corporate Social Responsibility (tanggung jawab sosial) LPD Desa Adat Kuta diwujudkan berlandaskan filosofi Tri Hita Karana yang terdiri dari 3 aspek yaitu Parhyangan, Pawongan dan Pelemahan. Hal ini dijelaskan oleh Bapak Buda Artha selaku Kepala LPD Desa Adat Kuta saat wawancara 8 Januari 2018 :

"Kalau melihat dari selama 22 tahun, tanggung jawab sosialnya banyak...disamping kita menyetorkan dana 20\% dari keuntungan, kalau gak salah itu sudah Rp 23.000.000.000 kita sudah nyetor ke Desa Adat dipakai untuk pembangunan Parhyangan, Palemahan dan Pawongan. "

Dari pernyataan diatas dapat disimpulkan bahwa CSR di LPD Desa Adat Kuta diimplementasikan dalam 3 aspek yaitu : Parhyangan, Pawongan, dan Palemahan. Corporate Social Responsibility pada LPD Desa Adat Kuta diimplementasikan sebagai berikut.

Pertama filosofi Parhayangan dalam THK menekankan perlunya diciptakan dan atau dijaga hubungan yang harmonis manusia dengan Tuhan. Menurut keyakinan umat Hindu bahwa pencipta, pemelihara dan pelebur alam beserta isinya adalah Tuhan Yang Maha Esa. Oleh karenanya, manusia memiliki utang terhadap-Nya, sehingga manusia memiliki kewajiban untuk memelihara hubungan harmonis kepada Tuhan (Sujana, 2015). Implementasi CSR di LPD berdasarkan aspek Parhyangan dilihat dari kontribusi yang diberikan LPD dalam kegiatan keagamaan dan pembangunan fasilitas keagamaan di lingkungan sekitar 
tempat LPD berdiri. Bapak Swarta, selaku Bendesa Adat Kuta saat wawancara 9 Januari 2018 menyampaikan sebagai berikut:

"Desa Kuta ini memiliki banyak kegiatan upacara keagamaan. Setiap 6 bulan sekali bisa 10 bahkan lebih kegiatan keagamaan yang kami gelar. LPD memberikan andil yang besar dalam berlangsungnya upacara keagamaan disini. LPD merupakan penyumbang tetap yang secara konsisten memberikan dana punia ketika ada Pujawali. Dana punia yang diberikan tidak hanya untuk upacara keagamaan tetapi sebagian juga digunakan untuk perbaikan fasilitas pura. LPD juga memberikan dana untuk para pemangku desa”.

Pernyataan Bapak Swarta menekankan pada istilah dana punia. Menurut Kusuma (2017) dana punia merupakan makna penting sebagai CSR berbasis Parhyangan yang terdiri dari tiga bentuk : pertama, dana punia dapat berupa materi yaitu: barang, uang, dan benda fisik yang berharga seperti bangunan pura atau tempat suci dan sarana ibadah. Kedua, ayahan merupakan aktivitas atau tenaga yang disumbangkan secara sukarela, baik untuk membantu kegiatan upacara maupun ritual, juga untuk seni kegiatan ritual dan membangun tempat ibadah serta merawatnya. Ketiga, pikayun pemberian yang tidak berwujud secara fisik dapat berupa gagasan atau ide, pikiran yang baik, dukungan yang baik, kondisi pikiran rahayu (pikayun rahayu), bahkan termasuk kebijakan serta pengendalian diri dalam bentuk pikiran yang positif dan baik.

Dari pernyataan informan dan peneliti sebelumnya dapat peneliti simpulkan bahwa dana punia yang diberikan LPD Desa Adat Kuta merupakan salah satu bentuk implementasi CSR dari aspek Parhyangan.

Ditambahkan lagi oleh Ibu Putu Suryati selaku pegawai LPD Desa Adat saat wawancara 9 Januari 2018 : 
"Saya sudah berkerja disini dari tahun 2005 sampai sekarang, sudah 13 tahun tu ya. Sebagai karyawan yang bekerja disini setiap pagi saya selalu maturan dulu sebelum memulai pekerjaan. Setiap purnama karyawan disini juga menggunakan baju adat (baju sembahyang). LPD punya program sendiri tentang kegiatan kegamaan yaitu tirtayatra. Biasanya setiap 2 Tahun sekali ada tirtayatra ke luar jawa, eh keluar Bali maksud saya. Kalau setahun sekali biasanya tirtayatra ke pura-pura yang ada di Bali saja."

Ttirtayatra (perjalanan suci) adalah usaha penyucian diri yang amat suci bahkan melebihi penyucian dengan yadnya. Bagi yang melaksanakannya akan menuju sifat satya, teguh, sayang dan tidak mudah marah (Suhardana, 2006:182183), seperti yang disebutkan dalam kitab suci Sarasamuccaya sloka 279 dan sloka 277 berikut ini:

Sada adridrairapi hi sakyam

Praptum naradhipa

Tirthabhigamanam punyam

Yajnerpi visisyate

Artinya:

Keutamaan tirtayatra itu amat suci

Lebih utama dari penyucian dengan yadnya

Dapat dilakukan oleh siapa saja

Termasuk oleh orang miskin

Sementara sloka 277 berbunyi sebagai berikut:

Akrodhamasca rajendra satya

Cilo drdhavratah

Atmopamasca bhutesu sa

Tirthaphalamasnute

Artinya:

Ada orang yang tidak pernah kerasukan rasa marah Satya, teguh dan sayang terhadap sesama mahkluk Tidak berbeda dengan mengurus dirinya sendiri Orang itu akan memperoleh pahala Tirtayatra 
Kegiatan tirtayatra (perjalanan suci) yang rutin dilakukan LPD setiap tahunnya termasuk salah satu refleksi dari harmoni antara manuusia dengan Tuhan (Parhyangan). Berdasarkan paparan diatas dapat disimpulkan implementasi CSR pada LPD Desa Adat Kuta dapat dilihat dari aspek Parhayangan yaitu memberikan dana punia untuk Pujawali, memberikan dana rutin bagi pemangku desa, membantu pembangunan atau renovasi pura, melakukan tirtayatra serta melakukan kegiatan-kegiatan lain yang berkaitan dengan peningkatan sradha dan bhakti krama Desa Adat Kuta.

Kedua filosofi Pawongan dalam THK menekankan perlunya diciptakan dan atau dijaga hubungan harmonis antara manusia dengan sesamanya. Pawongan dalam budaya Tri Hita Karana menekankan mengenai ajaran perbuatan sebab-akibat (karmaphala) dan tat-twam-asi (aku adalah kamu, kamu adalah aku) sebagai pegangan bagi perusahaan atau usaha bisnis Tat-twam-asi mengajarkan kesosialan tanpa batas karena diketahui bahwa "saya adalah kamu, kamu adalah saya", yang memiliki kesamaan, sehingga menolong orang lain (sesama) berarti menolong diri sendiri, menyakiti orang lain berarti menyakiti diri sendiri pula. Dalam kegiatan CSR, ajaran tat-twam-asi dapat menimbulkan sikap saling membantu dan menghormati antara perusahaan/lembaga dengan masyarakat. Salah satu bentuk tanggung jawab Lembaga Perkreditan Desa Adat Kuta terhadap masyarakat sekitar, yaitu semua pegawai LPD Desa Adat Kuta berasal dari masyarakat Desa Adat Kuta itu sendiri. 
Selanjutnya, Bu Yeni selaku nasabah dan masyarakat asli Desa Adat Kuta memberikan pernyataan mengenai peran Lembaga Perkreditan Desa Adat Kuta bagi masyarakat sekitar.

“Saya jadi nasabah disini dari tahun berapa ya... tahun 90'an. Ya udah lama banget, kan karena orang asli sini kan dari baru SMP udah boleh nabung disini.. Jadi dari tahun 93 dah pasnya. Untuk minjem disini kita dapet bunganya ringan gitu dibandingkan orang daerah yang minjem kesini gitu. Setiap tahun dia ulang tahun, ada Gebyarnya nanti. Gebyar LPD kayak isi jalan santainya trus ada pengundian hadiah. Ada juga reward pointnya berupa alat-alat upakara kayak bokoran. LPD disini membantu banget untuk permodalan, rata-rata disini kan wiraswasta jadi otomatis perlu modal. Jadi untuk masyarakat Kuta sendiri modalnya bunganya lunak. Untuk membantu masyarakat dibidang upacara dia itu ngasi bunga lunak untuk masyarakat yang minjem uang khusus upacara. Ada nama programnya khusus upakara saya lupa apa namanya. Disamping itu untuk pemangku desa ada yang meninggal semua biayanya ditanggung LPD. Untuk Pendidikan bagi anak saya LPD ada programnya Si Cerdas dan Si Made, tunjangan pendidikannya itu untuk tahun kedepan ada satu tahun sampai 5 tahun. LPD ini memang perannya yang pertama untuk Desa."

Penuturan dari $\mathrm{Bu}$ Yeni memberikan gambaran kepada peneliti bahwa $\mathrm{Bu}$ Yeni merasa sangat terbantu dengan adanya LPD di Desa Adat Kuta. Bu Yeni sebagai wirausaha yang menjual kerajinan tangan khas Bali sudah diberikan pinjaman dengan bunga ringan oleh LPD Desa Adat Kuta. Pinjaman yang diberikan oleh LPD ini sangat membantu Ibu Yeni untuk memperluas bisnis kerajinan tangannta. LPD juga mempunyai progam baru yang disebut BMW. Program ini dibentuk untuk meningkatkan jiwa wirausaha masyarakat Desa Adat Kuta. Berikut ini adalah pernyataan dari Bapak Buda Artha selaku Ketua LPD Desa Adat Kuta terkait program BMW.

"Program BMW itu kalau disingkat itu kan Berani Menjadi Wirausaha. Dimana program ini kita buatkan untuk meningkatkan daya usaha masyarakat yang khususnya adalah masyarakat yang akan menginjak 
berusaha di usaha-usaha yang skalanya kecil. Dimana kita memberikan modal usaha kepada calon BMW, itu per orang Rp 25.000.000 tanpa bunga tanpa jaminan. Nah, dimana dalam proses program BMW ini akan ada pendampingan dalam bentuk kontrol, pengawasan, pembinaan seperti itu".

Berdasarkan pernyataan Bapak Budha dan Ibu Yeni diatas peneliti menarik kesimpulan bahwa LPD Desa Adat Kuta telah menciptakan hubungan yang harmonis dengan masyarakat sekitar. Program BMW yang dibuat LPD merupakan salah satu bentuk kepedulian LPD terhadap masyarakat sekitar untuk mengembangkan usaha dan membangkitkan jiwa kewirausahaannya.

Dari paparan diatas dapat disimpulkan implementasi CSR di LPD Desa Adat Kuta dilihat dari aspek Pawongan yaitu diwujudkan pada kegiatan pemberdayaan krama desa melalui berbagai bidang sesuai kebutuhan masyarakat. Kegiatan-kegiatan itu diantaranya pemberian tunjangan pendidikan melalui program Si Cerdas dan Si Made bagi siswa berprestasi serta tidak mampu, santunan kematian, mendukung pelaksanaan upacara ngaben gratis setiap 4 tahun sekali, pemberian les gratis dan kursus tari bagi siswa, pembinaan olahraga prestasi, pembinaan seni kreativitas pemuda, memberikan pinjaman dengan bunga ringan bagi masyarakat sekitar.

Ketiga filosofi Palemahan dalam THK menekankan perlunya diciptakan dan atau dijaga hubungan harmonis antara manusia dengan lingkungannya. Di Bali, upacara yang dikenal untuk menjaga hubungan harmonis dengan alam lingkungan (bintang dan tumbuh-tumbuhan) yang disebut dengan tumpek bubuh dan tumpek kandang. Tumpek bubuh memberikan filosofis memberi sebelum menerima, dalam kaitannya dengan sumberdaya tumbuh-tumbuhan atau hayati. 
Sebelum manusia menikmati atau menggunakan tumbuh-tumbuhan untuk dikonsumsi sehari-hari, maka ia harus menanam atau memelihara dulu. Begitu pula tumpek kandang yang berarti manusia mencintai segala jenis satwa. Disamping itu manusia juga melakukan upacara (caru) untuk menjaga hubungan yang bersifat timbal balik antara manusia dan alam yang di ciptakan oleh Tuhan. Manajemen perusahaan dan pebisnis harus lebih disadari bahwa perusahaan tidak hanya memiliki tanggung jawab ekonomi untuk tujuan ekonomi (profit) untuk memenuhi kepentingan mereka. Perusahaan/lembaga harus menyelaraskan tanggung jawab ekonomi dengan tanggung jawab sosial dan lingkungan. Pebisnis termasuk LPD harus memerhatikan lingkungan hidup, baik lingkungan untuk kehidupan manusia, hewan, tumbuh-tumbuhan maupun lingkungan alam lainnya.

Implementasi CSR di LPD Desa Adat Kuta dilihat dari aspek Palemahan yaitu LPD Desa Adat Kuta mengeluarkan biaya-biaya untuk kegiatan upacara yadnya yang berhubungan dengan alam, LPD mengangkat karyawan khusus untuk menangani bidang kebersihan dan keasrian kantor, LPD memberikan dana untuk pengelolaan lingkungan adat yang sehat dan LPD juga berperan serta dalam menjaga kelestarian dan mendukung adat Budaya Bali.

Penelitian yang telah dilakukan di LPD Desa Adat Kuta sejalan dengan hasil penelitian Pertiwi tahun 2013 yang dilakukan di Discovery Kartika Plaza Hotel yaitu mengenai pelaksanaan CSR yang disebut sebagai CSR Terpadu (Integrated of CSR). Menurut Pertiwi (2013) CSR Terpadu (Integrated of CSR)) berorientasi pada budaya Bali, yaitu Tri Hita Karana yang terdiri atas harmonisasi manusia dengan Tuhan (Parhyangan), harmonisasi antar sesama 
ISSN: 2302-8556

manusia (Pawongan), dan harmonisasi antara manusia dengan alam (Palemahan), sehingga pemahaman ini mempunyai arti "usaha suatu lembaga dalam menjalankan kegiatan lembaganya secara lebih terpadu (terintegrasi), baik antara tujuan lembaga sebagai lembaga keuangan, keharmonisan hubungan dengan masyarakat dan alam, serta keyakinan perusahaan kepada Tuhan Yang Maha Esa sebagai pencipta segala- Nya di dunia ini”. Pemahaman CSR Terpadu (Integrated of CSR) menghasilkan tiga bentuk implementasi yang saling bersinergi dan memiliki kaitan satu sama lain, yaitu implementasi di masyarakat (community), di lingkungan (environment), dan hal-hal yang berkaitan dengan Tuhan (God). Ketiga bentuk implementasi yang saling bersinergi dan terintegrasi satu sama lain di dalam pemahaman "CSR Terpadu (Integrated of CSR)" tersebut dikonseptualisasikan ke dalam bentuk tabel berikut. 
Tabel 2.

Bentuk Implementasi Corporate Social Responsibility berlandaskan Filosofi Tri Hita Karana pada LPD Desa Adat Kuta

\begin{tabular}{|c|c|c|c|}
\hline No & $\begin{array}{c}\text { Bentuk } \\
\text { Implementasi }\end{array}$ & Manfaat & Nilai \\
\hline 1 & Masyarakat & 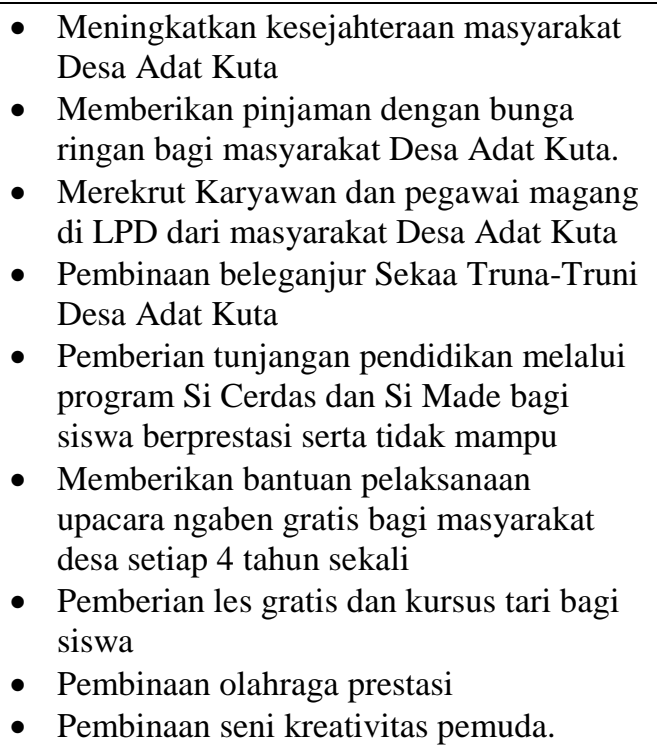 & $\begin{array}{ll}\text { - } & \text { THK-Pawongan } \\
\text { - } & \text { Awig-awig } \\
& \text { (aturan Desa } \\
& \text { Adat) } \\
\text { - } & \text { Teori Stakeholder } \\
\text { - } & \text { Teori Legitimasi } \\
\text { - } & \text { Teori Pemberian } \\
\text { - } & \text { Triple P (People) }\end{array}$ \\
\hline 2 & Lingkungan & $\begin{array}{l}\text { LPD Desa Adat Kuta mengangkat } \\
\text { karyawan khusus untuk menangani } \\
\text { bidang kebersihan dan keasrian kantor } \\
\text { - LPD berperan serta dalam menjaga } \\
\text { kelestarian dan mendukung adat Budaya } \\
\text { Bali. } \\
\text { - Melakukan kebersihan lingkungan } \\
\text { sebelum dan setelah pelaksanaan upacara } \\
\text { Pujawali di Desa Adat Kuta }\end{array}$ & $\begin{array}{l}\text { - } \quad \text { THK-Palemahan } \\
\text { - } \quad \text { Triple P (Planet) }\end{array}$ \\
\hline 3 & Tuhan & $\begin{array}{l}\text { - Memberikan dana punia untuk Pujawali } \\
\text { - Mang dilaksanakan setiap } 6 \text { bulan sekali } \\
\text { pemangku desa setiap bulan } \\
\text { - Membantu pembangunan atau renovasi } \\
\text { pura } \\
\text { - Melakukan Tirta Yatra secara rutin setiap } \\
\text { Tahun } \\
\text { - Memberikan kesempatan seluruh } \\
\text { karyawan LPD untuk melakukan } \\
\text { persembahyangan pada hari suci Agama } \\
\text { Hindu } \\
\text { Memberikan kebijakan kepada karyawan, } \\
\text { setiap Purnama ke kantor menggunakan } \\
\text { baju Adat persembahyangan. }\end{array}$ & $\begin{array}{l}\text { - THK- } \\
\text { Parhyangan } \\
\text { - } \quad \text { Spirituals }\end{array}$ \\
\hline
\end{tabular}

Sumber : Data dioalah, 2018 


\section{SIMPULAN}

LPD Desa Adat Kuta melaksanakan CSR berlandaskan filosofi Tri Hita Karana. Unsur "3P" (Planet, People, Profit) yang terkandung dalam dalam CSR memiliki kemiripan dengan filosofi Tri Hita Karana. LPD Desa Adat Kuta juga menambahkan hal-hal yang berkaitan dengan Tuhan (unsur Parhyangan yang terkandung dalam filosofi THK) dalam mengimplementasikan CSR terpadu. Setiap filosofi yang dimiliki masyarakat Hindu-Bali (termasuk THK) selalu meyakini bahwa Tuhan sebagai faktor penting dalam semua sendi kehidupan dan setiap kegiatan yang dilaksanakan. Dalam pengelolaan LPD, pengurus LPD telah menerapkan CSR secara terpadu yang berdasarkan filosofi THK. Implementasi CSR terpadu dapat dikatakan sebagai salah satu bentuk perkembangan konsep CSR yang seiring kemajuan jaman semakin membutuhkan nilai-nilai spiritual yang berkaitan dengan nilai Ketuhanan sebagai landasan kuat untuk menjalankan kegiatan bisnis.

Penelitian ini hanya meneliti pada satu situs penelitian yaitu LPD Desa Adat Kuta, penelitian selanjutnya bisa dilakukan pada LPD lainnya atau lembagalembaga lainnya. Penelitian ini menggunakan informan penelitian yang terlibat dalam operasional LPD dan menggunakan study kasus, untuk memperoleh pemahaman dan pengalaman dari informan yang lebih utuh bisa dilakukan dengan pendekatan interpretif fenomenologi dan menambahkan informan yaitu masyarakat Kuta yang tidak terlibat dalam operasional LPD. 


\section{REFERENSI}

Asocio (Asian-Oceanian Computing Industry Organization). 2004. Corporate Social Responsibility. ASOCIO Policy Paper, June.

Bagiada dan Darmayasa, I Nyoman. 2015. Implementasi Filosofi Tri Hita Karana dalam Pengungkapan Tanggung Jawab Sosial pada Lembaga Perkreditan Desa (LPD), Prosiding Simposium Nasional Akuntansi Vokasi ke-4, Manado, 28-30 Mei 2015.

Bank Indonesia. 2016. Kajian Ekonomi Regional Provinsi Bali Triwulan.

Bogdan, Robert C. \& Sari Knopp Biklen, Qualitative Research for Education: An. Indroduction to Theory and Methods, Boston: Allyn and bacon, Inc, 1982.

Damayanthi, 2011. Pengungkapan Tanggung Jawab Sosial Lembaga Perkreditan Desa (LPD) Berdasarkan Filosofi Tri Hita Karana, Jurnal Ilmiah Akuntansi \& Bisnis, Vol 6. No. 2.

Denzin, Norman K. and Lincoln S. Yvonna. 2000. Handbook of Qualitative Research. London: Sage Publication.

Dwirandara, Anak Agung Ngurah Bagus. 2011. Rekrontruksi Metoda Penilaian Aset dengan Filosofi "Tri Hita Karana”. (Disertasi). Malang: Universitas Brawijaya.

Elkington, Jhon. 1998. Cannibals with Forks :The Triple Bottom Line of $21^{\text {st }}$ Centaury Business. Oxford. UK: Capstone.

Epstein, M.J. dan M. Friedman. 1994. "Social Disclosure and the Individual Investor". Accounting, Auditing \& AccountabilityJournal Vol. 7, No. 4, hlm $94-109$.

Gray, R, Kouhy, R and Lavers, S. 1995. "Corporate Social and Environmental Reporting: A Review of The Literatre and Longitudinal Study of UK Disclosure". Accounting Auditing and Accountability Journal. Vol 8. No.2 pp 47-77.

Heinze, D. C. 1976. Financial Correlates Of A Social Involvement Measure. Akron Business and Economics Review. Vol.7 No.1. pp 48-51.

Kusuma, I Gusti Agung Eka Teja. 2017. Tri Hita Karana sebagai Dasar Pengembangan Model CSR serta Dampaknya terhadap Loyalitas Pelanggan (Studi CSR pada Industri Perbankan di Provinsi Bali). (Disertasi). Denpasar : Universitas Udayana. 
Mauss, Marcel. (1992) 2002. The Gift : The Form and Reason for Exchange in Archaic Societies. London: Routledge Classic.

Moleong, J.Lexy. 2016. Metode Penelitian Kualitatif. Bandung : PT REMAJA ROSDAKARYA

Peraturan Daerah Provinsi Bali Nomor 3 Tahun 2017. Tentang Perubahan ketiga atas Peraturan Daerah Provinsi Bali Nomor 4 Tahun 2012. Tentang Lembaga Perkreditan Desa.

Peraturan Daerah Provinsi Bali Nomor 4 Tahun 2012. Tentang Perubahan kedua atas Peraturan Daerah Provinsi Bali Nomor 8 Tahun 2002. Tentang Lembaga Perkreditan Desa.

Pertiwi dan Ludigdo, 2013. Implementasi Corporate Social Responsibility Berlandaskan Budaya Tri Hita Karana. Jurnal Akuntansi Multiparadigma, Vol. 4, No. 3.

Ratih, I Dewa Ayu. 2016. Kepemilikan Manajerial dan Profitabilitas pada Nilai Perusahaan dengan Pengungkapan tanggung Jawab Sosial sebagai Variabel Pemoderasi. E-Jurnal Akuntansi Universitas Udayana.14.2Februari (2016): 1510-1538

Suardikha, I.M.S. 2012. Pengaruh Implementasi Budaya Tri Hita Karana terhadap Penggunaan Sistem InformasiAkuntansi Dimediasi KeyakinanDiri atas Komputer, Keinovatifan Personal, Persepsi Kegunaan, danPersepsi Kemudahan Penggunaan pada Bank Perkreditan Rakyat di Bali. (Disertasi). Malang:Universitas Brawijaya.

Sujana, Dwirandra, Putri dan Suardikha.2015. Akuntabilitas dalam Perspektif Budaya Lokal pada Lembaga Perkreditan Desa (LPD). Laporan Penelitian. Nomor: 1455/UN.14.1.12.II/KP.01.04/SPK/2015

Suprasto, Irwan, Rosidi dan Gugus Irianto. 2015. Accountability of Local Regional Financial Management Based Tri Hita Karana (Study at Badung Government-Indonesia). Australian Journal of Basic and Applied Sciences. 9 (31) September 2015. Pages: 509-516

Tenaya, G. A. I. 2007. Analisis Falsafah dan Konsep Akuntansi dalam Perspektif Filsafat Kultur Bali Tri Hita Karana dan Kesadaran Internal Lembaga terhadap Hukum perusahaan. Tesis. Universitas Brawijaya

Wang, L. \& H. Juslin. 2009. The Impact of Chinese Culture on Corporate Social Responsibility: The Harmony Approach.Journal of Business Ethics (2009) 88, hal 433-451. 